(C) 2022, The Authors. Published by Elsevier Inc. and Fass Inc. on behalf of the American Dairy Science Association ${ }^{\circledR}$. This is an open access article under the CC BY license (http://creativecommons.org/licenses/by/4.0/).

\title{
A high-concentrate diet provokes inflammation, endoplasmic reticulum stress, and apoptosis in mammary tissue of dairy cows through the upregulation of STIM1/ORAl1
}

\author{
Meijuan Meng, Lairong Wang, Yan Wang, Nana Ma, Wan Xie, Guangjun Chang, and Xiangzhen Shen* \\ Ministry of Education Joint International Research Laboratory of Animal Health and Food Safety, College of Veterinary Medicine, \\ Nanjing Agricultural University, Nanjing 210095, Jiangsu, P. R. China
}

\begin{abstract}
High-concentrate feeding can induce subacute ruminal acidosis, which leads to mammary tissue injury in dairy cows. Therefore, the purpose of this research was to evaluate the effect of high-concentrate feeding on STIM1 (stromal interaction molecule 1)/ORAI1 (Orai calcium release-activated calcium modulator 1)-mediated inflammation, endoplasmic reticulum stress (ERS), and apoptosis in the mammary tissue of dairy cows. A total of 12 healthy mid-lactating Holstein cows of similar weight were randomly allotted into the following 2 groups: a high-concentrate (HC) group (concentrate:forage $=6: 4$ ) and a low-concentrate $(\mathrm{LC})$ group (concentrate:forage $=4: 6$ ). The trial lasted for $3 \mathrm{wk}$. After the feeding experiment, rumen fluid, lacteal vein blood, and mammary tissue samples were collected. The results showed that the HC diet significantly increased blood lipopolysaccharide levels, decreased ruminal $\mathrm{pH}$, and upregulated the concentrations of $\mathrm{Ca}^{2+}$ and proinflammatory cytokines, including TNF- $\alpha$, IL-1 $\beta$, and IL- 6 , and the enzyme activities of caspase-3, caspase-9, PKC, and IKK. The upregulation of STIM1, ORAI1, PKC $\alpha$, IKK $\beta$, phosphorylatedI $\kappa \mathrm{B} \alpha$, phosphorylated-p65, TNF- $\alpha$, and IL- $1 \alpha$ proteins in the HC group indicated activation of the STIM1/ ORAI1-mediated inflammatory signaling pathway compared with that in the LC group. The HC diet also induced ERS by increasing the mRNA and protein abundances of GRP78, CHOP, PERK, ATF6, and IRE1 $\alpha$ in the mammary tissue. Compared with the LC group, the mRNA expression levels and protein abundances of caspase-3, cleaved caspase-3, caspase-9, and BAX were markedly increased in the $\mathrm{HC}$ group. However, the mRNA and protein expression levels of Bcl-2 were significantly decreased in the HC group.
\end{abstract}

Received August 21, 2021.

Accepted December 6, 2021.

*Corresponding author: xzshen@njau.edu.cn
Therefore, this study demonstrated that the $\mathrm{HC}$ diet can activate the store-operated calcium entry channel by upregulating the expression of STIM1 and ORAI1 and induce inflammation, ERS, and apoptosis in the mammary tissue of dairy cows.

Key words: high-concentrate diet, STIM1, ORAI1, dairy cow

\section{INTRODUCTION}

To improve production performance and economic returns, dairy cows are often fed large amounts of concentrate feeds, which are rich in easily fermentable carbohydrates. Although concentrated feed can greatly improve cows' milk yield, it affects their health at the same time. These concentrated feeds are high in starch and energy and low in fiber, and too much concentrate intake in ruminants leads to the accumulation of VFA in the rumen and a decrease in ruminal $\mathrm{pH}$, which can cause SARA (Penner et al., 2010). Long-term exposure to SARA not only reduces the feed intake of dairy cows but also increases the risk of laminitis, liver abscess, and inflammatory reactions. It seriously endangers the health of dairy cows and reduces milk yield and quality, thereby causing substantial economic losses to the dairy industry (Chang et al., 2015a). Under SARA conditions, a large amount of LPS is released by gramnegative bacteria in the rumen, which passes through the epithelial barrier of the digestive tract, transfers to the circulatory system, and migrates to the mammary tissue, where it causes an inflammatory reaction in mammary tissue and produces a large number of cytokines and acute phase proteins (Gozho et al., 2007).

As a common second messenger, $\mathrm{Ca}^{2+}$ is widely distributed in cells and involved in many cellular functions, including inflammation, energy metabolism, and cell death. When intracellular $\mathrm{Ca}^{2+}$ is elevated, protein kinase $\mathrm{A}$ and protein kinase $\mathrm{C}$ can be activated, which activate regulatory protein kinases and nuclear transcription factors to regulate the inflammatory response. The increase in intracellular $\mathrm{Ca}^{2+}$ levels may 
be due to the release of free calcium from the endoplasmic reticulum (ER) or the entry of extracellular $\mathrm{Ca}^{2+}$ into cells (Gregory et al., 2004; Yan et al., 2016). In addition, store-operated calcium entry (SOCE) is the main entry channel for $\mathrm{Ca}^{2+}$ in nonexcited cells. The calcium receptor STIM1 in the ER and the calcium channel ORAI1 in the cytoplasm are important components of SOCE (Li et al., 2017; Derler et al., 2018; Fahrner et al., 2018). The ER is a storage site for intracellular $\mathrm{Ca}^{2+}$ and plays an important physiological role in cells. A variety of physiological and pathological conditions can cause $\mathrm{Ca}^{2+}$ depletion in the ER, resulting in an imbalance in intracellular calcium homeostasis and leading to endoplasmic reticulum stress (ERS). Glucose-regulated protein 78 (GRP78) is a molecular chaperone of the ER that is involved in protein folding and processing in the ER to maintain ER homeostasis (Louessard et al., 2017). When the ER is stimulated by external factors, this can cause an imbalance in $\mathrm{Ca}^{2+}$ levels by increasing the number of unfolded and misfolded proteins in the ER (Wang et al., 2018a). The receptors IRE1 $\alpha$ (inositol-requiring kinase $1 \alpha$ ), PERK (protein kinase R-like endoplasmic reticulum kinase), and ATF 6 (activating transcription factor 6) then dissociate from GRP78/BIP and are activated accordingly (Fernández-Bautista et al., 2017), thus activating the unfolded protein response (UPR) and downstream cascading signaling pathways (Park et al., 2017). Therefore, the high expression of GRP78 can be used as a marker of ERS and UPR activation (Schröder and Kaufman, 2005; Xu et al., 2005). There is a certain relationship between the increase in intracellular $\mathrm{Ca}^{2+}$ concentration and apoptosis (Berridge et al., 2003; Brough et al., 2005a,b; Szabadkai and Rizzuto., 2004). The influx of extracellular $\mathrm{Ca}^{2+}$ can disrupt intracellular homeostasis, leading to intracellular calcium overload, which results in apoptosis (Pinton et al., 2001; Targos et al., 2005). Previous studies have shown that STIM1-mediated SOCE can promote the apoptosis of tumor cells by inducing calcium flow (Yang et al., 2018) and that hyperglycemia induces apoptosis in human umbilical vein epithelial cells through SOCE (Tamareille et al., 2006). Previous research has also reported that extracellular $\mathrm{Ca}^{2+}$ influx, which is mediated by SOCE in a STIM1-dependent manner, is involved in NaB-induced apoptosis in colon cancer cells (Sun et al., 2012).

At present, most studies on the function of STIM1/ ORAI1 mainly focus on its effects on the occurrence, progression, and prognosis of various malignant tumors and lung injury (Song et al., 2018; Wang et al., 2018b; Debant et al., 2019; Karacicek et al., 2019). However, few studies have investigated the effect of STIM1/
ORAI1 on SARA-induced mammary tissue injury in dairy cows. Therefore, there is an urgent need to investigate the mechanism of STIM1/ORAI1 regulation in SARA-induced mammary injury in dairy cows and provide a new target for the treatment of mastitis. Therefore, we studied the regulatory effect of STIM1/ORAI1 on inflammation, ERS, and apoptosis in the mammary tissue of dairy cows induced by a high-concentrate diet, which can provide a new perspective on the molecular mechanism of SARA-induced mammary tissue injury in dairy cows.

\section{MATERIALS AND METHODS}

\section{Ethics Statement}

Our animal experiment was conducted following the Guidelines for Experimental Animals of the Ministry of Science and Technology (2006, Beijing, China). All animal procedures were approved by the Animal Ethics Committee of Nanjing Agricultural University.

\section{Animals and Experimental Design}

A total of 12 healthy, multiparous mid-lactating Holstein cows with similar weights were randomly allotted into 2 groups, with 6 replicates per group. Cows were fed the following 2 experimental diets: a highconcentrate $(\mathbf{H C})$ diet (concentrate:forage $=6: 4$ ) and a low-concentrate $(\mathbf{L C})$ diet (concentrate:forage $=4: 6$ ). The cows were fed in a single stall. They were fed twice a day at 0800 and $1700 \mathrm{~h}$ and were given water freely. Before the experiment, rumen fistulas were installed in each of the experimental cattle. The experiment lasted for $3 \mathrm{wk}$. The dietary composition and nutrient composition of each experimental group are shown in Table 1.

\section{Sample Collection and Treatment}

At the end of the experiment, all animals were euthanized, and the mammary tissue was collected. The mammary tissue was cut into small pieces, and the surface milk and blood were washed away with saline. Then, the mammary tissue was immediately frozen in liquid nitrogen and stored at $-80^{\circ} \mathrm{C}$ for laboratory testing. In addition, the rinsed mammary tissue was cut into approximately $1 \mathrm{~cm}^{3}$ pieces and fixed with $4 \%$ paraformaldehyde for subsequent histological analysis.

Blood was collected via the lacteal vein catheter of the experimental cows. Then, the blood samples were centrifuged at $3,018 \times g$ at $4^{\circ} \mathrm{C}$ for $15 \mathrm{~min}$. The plasma was then collected and stored at $-20^{\circ} \mathrm{C}$ for the determination of pro-inflammatory cytokine content, such 
Table 1. Ingredients and nutrient contents of the low-concentrate (LC) and high-concentrate (HC) experimental diets (DM basis, \%)

\begin{tabular}{lrr}
\hline & \multicolumn{2}{c}{ Diet (content) } \\
\cline { 2 - 3 } Item & \multicolumn{1}{c}{ LC } & \multicolumn{1}{c}{$\mathrm{HC}$} \\
\hline Ingredient & & \\
Maize & 19.40 & 24.92 \\
Soybean meal & 13.50 & 13.48 \\
Barley & 0.00 & 12.00 \\
Distillers dried grains with soluble & 3.80 & 5.91 \\
Silage corn & 12.00 & 6.00 \\
Alfalfa & 24.00 & 17.00 \\
Oat grass & 24.00 & 17.00 \\
Limestone & 0.80 & 1.48 \\
CaHPO & 1.10 & 0.92 \\
NaCl & 0.40 & 0.37 \\
Premix ${ }^{1}$ & 1.00 & 0.92 \\
Total & 100.00 & 100.00 \\
Nutrient level & \\
CP (\%) & & \\
Calcium (\%) & 16.16 & 16.21 \\
Phosphorus (\%) & 1.14 & 1.18 \\
NDF (\%) & 0.52 & 0.51 \\
NFC (\%) & 36.14 & 29.92 \\
Ash (\%) & 35.39 & 42.34 \\
Net energy (MJ/kg) & 5.97 & 4.87 \\
Crude fat (\%) & 1.57 & 1.64 \\
Starch (\%) & 3.05 & 3.05 \\
NFC/NDF & 17.96 & 27.82 \\
1 & 0.99 & 0.71 \\
\hline
\end{tabular}

${ }^{1}$ The premix provided the following per kilogram of diet: vitamin $\mathrm{A}$, $22.5 \mathrm{kIU} / \mathrm{kg}$; vitamin $\mathrm{D}_{3}, 5.0 \mathrm{kIU} / \mathrm{kg}$; vitamin $\mathrm{E}, 37.5 \mathrm{IU} / \mathrm{kg}$; vitamin $\mathrm{K}_{3}, 5.0 \mathrm{mg} / \mathrm{kg} ; \mathrm{Cu}, 25.6 \mathrm{mg} / \mathrm{kg} ; \mathrm{Fe}, 159.3 \mathrm{mg} / \mathrm{kg} ; \mathrm{Zn}, 111.9 \mathrm{mg} / \mathrm{kg}$; and $\mathrm{Mn}, 63.5 \mathrm{mg} / \mathrm{kg}$.

${ }^{2}$ Nutrient levels were estimated values.

as IL-1 $\beta$, IL-6, and TNF- $\alpha$. The mammary tissue was collected and kept at $-80^{\circ} \mathrm{C}$ for further measurement after the cows were killed.

\section{Ruminal pH, Plasma LPS, and Proinflammatory Cytokine Measurements}

On the $\mathrm{d} 20$ and 22 of the trial period, ruminal fluid was collected through the rumen fistula after the morning feeding. The first collection was recorded as $0 \mathrm{~h}$, followed by collection every $2 \mathrm{~h}$ until $12 \mathrm{~h}$. The ruminal fluid collected was immediately filtered through 4 layers of gauze, and then the ruminal $\mathrm{pH}$ was measured with a HI9125 portable waterproof $\mathrm{pH} / \mathrm{ORP}$ meter (Hanna Instruments) and recorded. This measurement was conducted 3 times each time, and the average value was taken.

The plasma LPS concentration was determined by the instructions of the Chromogenic End-point Tachypleus Amebocyte Lysate Assay Kit (Xiamen Limulus Reagent Experimental Factory Co., Ltd.). This kit has a minimum detection limit of $0.01 \mathrm{EU} / \mathrm{mL}$ for plasma. Plasma samples were diluted 10 times with a blood treatment agent and then tested; $0.1 \mathrm{~mL}$ of plasma was added to $0.9 \mathrm{~mL}$ of blood treatment agent, and the mixture was evenly mixed. The sample was heated for 10 min at $70^{\circ} \mathrm{C}$, and then the samples, which had already been diluted 10 times, were processed according to the kit instructions.

The concentrations of the proinflammatory cytokines IL-6 (CK-EN77030), IL-1 $\beta$ (CK-EN77027), and TNF- $\alpha$ (CK-EN77163) in the plasma were measured by ELISA kits purchased from Ruixin Biotech.

\section{IKK and PKC Kinase Activity Assays}

The mammary tissue homogenate was used to measure IKK and PKC kinase activity. The IKK (CKEN78238, Ruixin Biotech) and PKC (CK-EN78239, Ruixin Biotech) kinase activity assays were carried out following the manufacturer's protocols.

\section{Immunohistochemical Staining Analysis}

First, the mammary tissue was fixed with paraformaldehyde, dehydrated, embedded in paraffin, and deparaffinized. After deparaffinization, the sections were blocked with $3 \% \mathrm{H}_{2} \mathrm{O}_{2}$ at room temperature for $25 \mathrm{~min}$ and washed with PBS. Then, the sections were blocked for $30 \mathrm{~min}$ at room temperature $\left(24^{\circ} \mathrm{C}\right)$ in $3 \% \mathrm{BSA}$ and incubated overnight at $4^{\circ} \mathrm{C}$ with specific antibodies in dilution buffer for caspase-9, GRP78, STIM1, and ORAI1. Subsequently, the sections were washed with PBS, incubated with specific horseradish peroxidaseconjugated secondary antibodies, and then washed with PBS again. Finally, the sections were counter-stained with hematoxylin for $3 \mathrm{~min}$, dehydrated, and covered with a coverslip. The results were captured by using an abiological microscope system (Chongqing MIC Technology Co., Ltd.).

\section{RNA Analysis}

First, the mammary tissue was ground into powder in liquid nitrogen. Approximately $50 \mathrm{mg}$ of mammary tissue was weighed, and according to the manufacturer's requirements, total RNA was isolated from mammary tissue using RNAiso Plus (Takara Co.). Then, the concentration and purity of the extracted total RNA were determined using a NanoDrop 2000 (Thermo Fisher Scientific Inc.). A total of $1,000 \mathrm{ng}$ of total RNA was used for cDNA generation using the Prime Script 158 RT Master Mix Perfect Real Time Kit (Takara Co.). The primers were designed and assessed with Premier 6.0 software (Premier Biosoft International), and the primers were commercially synthesized by Shanghai Genery Biotech Co. The relative levels of the genes as- 
sociated with the SOCE channel (STIM1 and ORAI1), inflammatory response-related genes $(I L 6, I L 8, I L 10$, TNFA, RELA, and IKB), acute phase proteins (SAA3, $H P$, and $L B P$ ), ERS (GRP78, CHOP, ATF6, PERK, and IRE1A), and apoptosis (CASP3, CASP8, CASP9, $B A X$, and BCL2) were tested by real-time quantitative PCR, which was performed using a SYBR Premix Ex Taq Kit (Takara Co.) in accordance with the manufacturer's protocol. The sequences of the target primers are provided in Table 2. The PCR was conducted on the ABI 7300 Fast Real-time PCR System (Applied Biosystems, Foster City), and the conditions were programmed as follows: denaturation at $95^{\circ} \mathrm{C}$ for $15 \mathrm{~s}$, followed by 40 cycles of $95^{\circ} \mathrm{C}$ for $5 \mathrm{~s}$ and $60^{\circ} \mathrm{C}$ for $31 \mathrm{~s}$. All samples were tested 3 times, and GAPDH was chosen as the internal control. The real time quantitative PCR results were analyzed using the $2^{-\Delta \Delta \mathrm{Ct}}$ method to calculate mRNA abundance levels.

\section{Western Blotting Analysis}

Approximately $100 \mathrm{mg}$ of mammary tissue was extracted, total protein was extracted with radioimmunoprecipitation assay (RIPA) lysis buffer (Biosharp Life Sciences), and the protein concentration was determined by a bicinchoninic acid protein assay kit (Thermo Fisher Scientific Inc.). The protein concentration of each sample was diluted to $4 \mu \mathrm{g} / \mu \mathrm{L}$. After denaturing with SDS loading buffer at $99^{\circ} \mathrm{C}$ for $5 \mathrm{~min}$, the proteins were separated by $10 \%$ or $7.5 \%$ SDSPAGE and transferred to a nitrocellulose membrane (Millipore) at $4^{\circ} \mathrm{C}$. The membrane was blocked for 1 $\mathrm{h}$ at room temperature in $10 \%$ nonfat milk or BSA (for phosphorylated proteins). The blocked membranes were incubated overnight at $4^{\circ} \mathrm{C}$ with the specific antibodies in dilution buffer against the following proteins: IL-1 $\alpha$ (H-159; 1:200, sc-7929, Santa Cruz Biotechnology); NF-кB p65 (1:1,000, AF0246, Beyotime) and

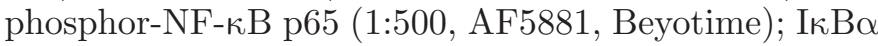
(1:1,000, AF2176, Beyotime); phospho-I $\mathrm{B} \alpha$ (1:1,000, AF1870, Beyotime); IL-1及 (1:500, AF5103, Affinity); TNF- $\alpha$ (1:1,000, A11534, Abclonal); STIM1 (1:1,000, AF2614, Beyotime); ORAI1 (1:5,000, 66223-1-Ig, ProteinTech); GRP78 (1:1,000, AF0171, Beyotime); CHOP (1:1,000, AC532 Beyotime); PERK (1:1,000, D11A8; Cell Signaling) and phospho-PERK (1:500,

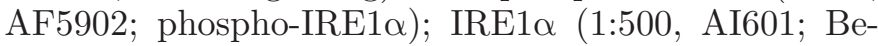
yotime); phospho-IRE1 $\alpha$ (1:500; AF5842, Beyotime); ATF6 (1:500, AF6243, Beyotime); caspase-3 (1:1,000, AC030, Beyotime); cleaved caspase-3 (1:1,000, AC033, Beyotime); caspase-9 (1:1,000, AC062, Beyotime); BAX (1:1,000, AF1270); and Bcl-2 (1:1,000, AB112, Beyotime). Then, the membrane was washed with Tween in Tris-buffered saline and $0.1 \%$ Tween 20 Detergent (TBST) and incubated with the corresponding specific secondary antibody at room temperature for 2 h. Finally, the incubated protein bands were washed in TBST. The protein abundance signals were visualized

Table 2. Primers used in the quantitative real-time PCR analysis

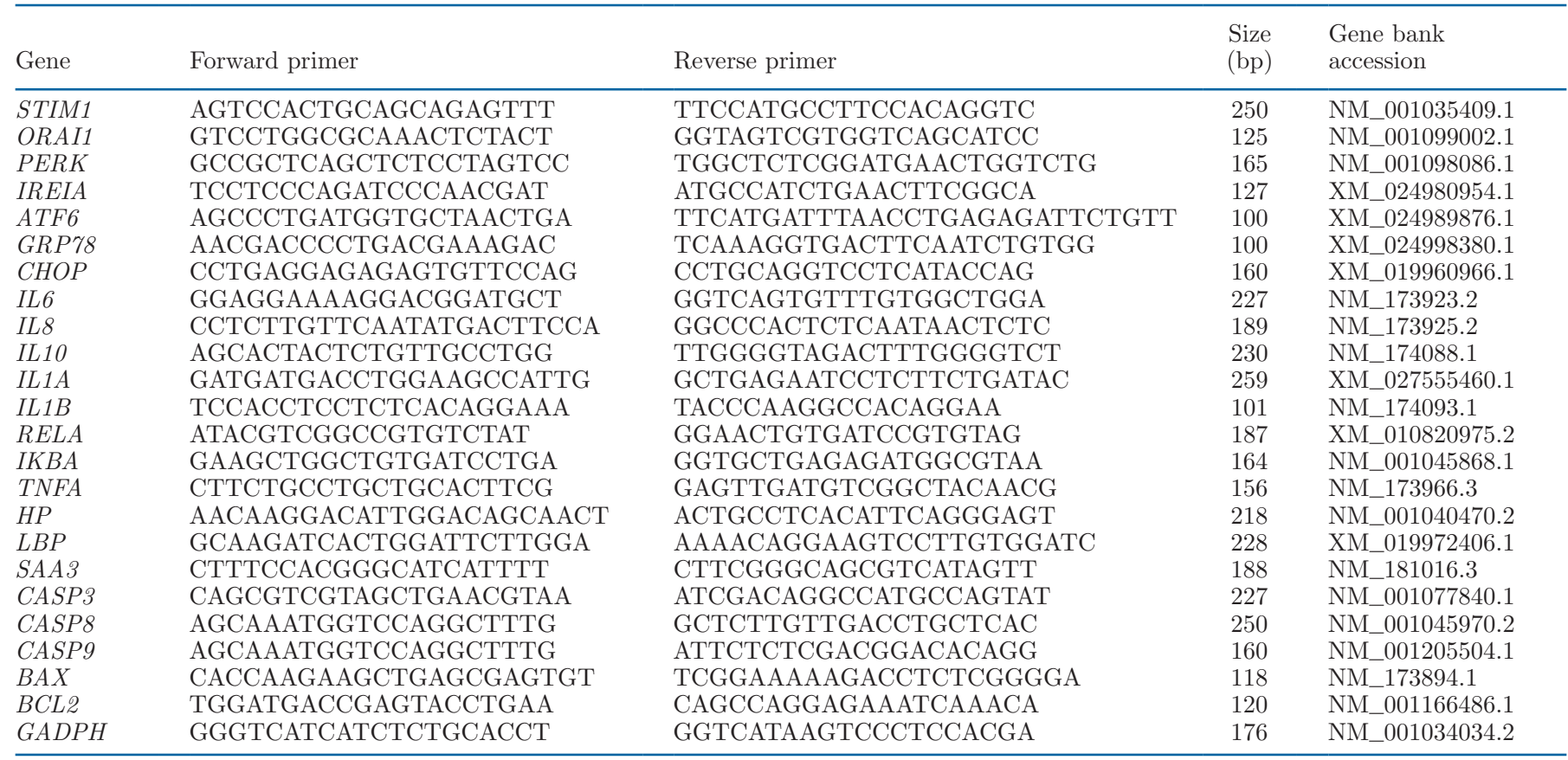


by an ECL Plus Kit (Vazyme) using a ChemiDoc MP system (Bio-Rad). Band intensity was analyzed with Image Lab software (version 5.2.1.62311, Bio-Rad), and $\beta$-actin (1:1,000; AA128, Beyotime) was considered a reference protein for normalization.

\section{Statistical Analysis}

All processing was carried out in triplicate. The initial data were processed using Excel 2020 and analyzed via independent-samples $t$-tests using the SPSS software package (SPSS Statistics 20, IBM Corp.). The data were expressed as the means \pm SEM; $P<0.05$ indicated a significant difference, $P<0.01$ indicated an extremely significant difference, and $P>0.05$ indicated no significant difference.

\section{RESULTS}

\section{Ruminal $\mathrm{pH}$ and Blood LPS}

The ruminal $\mathrm{pH}$ in the $\mathrm{HC}$ group was significantly lower than that of the LC group $(P<0.01)$, and the ruminal pH was below 5.6 for more than $3 \mathrm{~h} / \mathrm{d}$ (Figure 1A), indicating that the SARA model was successfully induced. Additionally, the concentration of LPS was significantly enhanced with the $\mathrm{HC}$ diet $(P<0.01$, Figure 1B).

\section{Effect of an HC Diet on the SOCE Channel}

The SOCE channel mainly consists of STIM1 and ORAI1. In nonexcited cells, the SOCE channel is mainly mediated by high calcium levels. When cells are stressed and the calcium pool in the ER is depleted, the SOCE channel will be activated, which causes intracellular $\mathrm{Ca}^{2+}$ to flow in. Therefore, we investigated whether the $\mathrm{HC}$ diet affects the SOCE channel. As shown in Figure 2B, the mRNA expression levels of STIM1 $(P<0.01)$ and ORAI1 $(P<0.05)$ in the mammary tissue of cows fed the $\mathrm{HC}$ diet were significantly higher than those of cows fed the LC diet. Additionally, compared with the LC diet, the protein expression levels of STIM1 $(P<0.05)$ and ORAI1 $(P<0.01)$ were significantly upregulated in the mammary tissue of the $\mathrm{HC}$ diet. To further confirm our results, the content of $\mathrm{Ca}^{2+}$ in the mammary tissue of dairy cows was determined. We found that the $\mathrm{HC}$ diet significantly increased the $\mathrm{Ca}^{2+}$ content in the mammary tissue of dairy cows in comparison to the LC diet $(P<0.01 ;$ Figure $2 \mathrm{~A})$. These results showed that SARA activated the SOCE channel by upregulating the expression of the STIM1 and ORAI1 genes and proteins, thereby leading to calcium influx.

\section{Effects of an HC Diet on the Protein Expression and Enzyme Activity of IKK and PKC}

Compared with the LC diet, the HC diet significantly increased the activity of the IKK $(P<0.01)$ and PKC $(P<0.01)$ kinases. The protein expressions of IKK- $\beta$ $(P<0.05)$ and PKC- $\alpha(P<0.01)$ in the HC diet were significantly higher than that in the mammary tissue of the LC diet (Figure 3).

\section{Effects of an HC Diet on NF-KB Activation in the Mammary Tissue of Dairy Cows}

As shown in Figure 4A-C, we found that the $\mathrm{HC}$ diet increased the concentrations of IL- $1 \beta$, IL- 6 , and TNF- $\alpha$
A

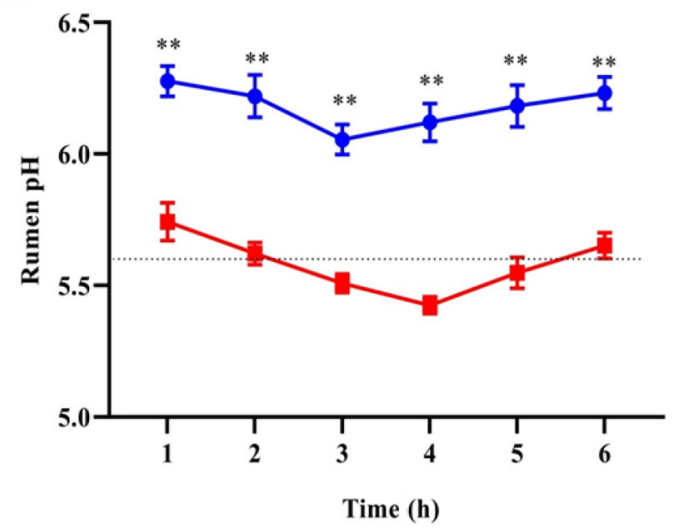

B
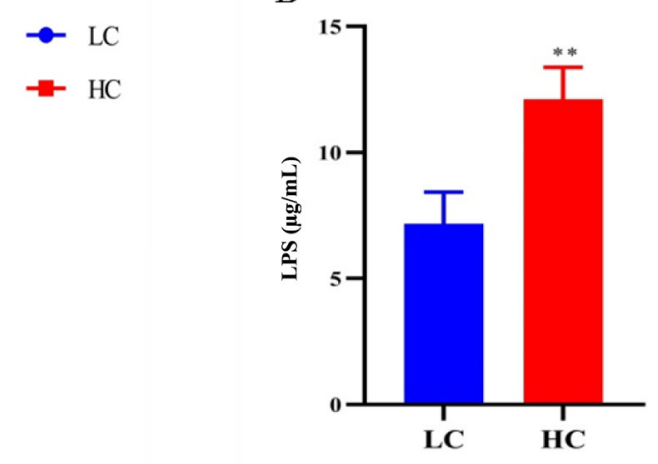

Figure 1. Effect of high-concentrate diet feeding on the $\mathrm{pH}$ and concentration of LPS. Ruminal pH values of the low-concentrate diet (LC) and high-concentrate diet (HC) at different time points (A). The LPS content in the lacteal vein of LC and HC diets (B). The differences between treatments are indicated at ${ }^{* *} P<0.01$. Data were analyzed with independent $t$-tests and expressed as the mean \pm SEM. 
in comparison with the $\mathrm{LC} \operatorname{diet}(P<0.01)$. Figure $4 \mathrm{D}-\mathrm{F}$ shows the gene expression involved in the inflammatory response. The mRNA expression levels of the acute phase proteins $\operatorname{LBP}(P<0.01), H P(P<0.01)$, and $S A A 3(P<0.05)$ in the mammary tissue of the $\mathrm{HC}$ diet showed a significant upregulation compared with the LC diet (Figure 4E). Additionally, RELA ( $P$ $<0.05)$, IKBA $(P<0.01)$, IL6 $(P<0.05)$, IL8 $(P<$ $0.05)$, IL1A $(P<0.01), I L 1 B(P<0.01)$, and TNFA $(P<0.01)$ mRNA expression was upregulated in the mammary tissue of the HC diet. However, IL10 mRNA expression was markedly reduced in the $\mathrm{HC}$ diet (Figure $4 \mathrm{D}$ and Figure $4 \mathrm{~F}$ ). Protein expression of $\mathrm{I} \kappa \mathrm{B} \alpha$ and p65 was not significantly different between the 2 groups $(P>0.05)$. However, the protein abundances of both

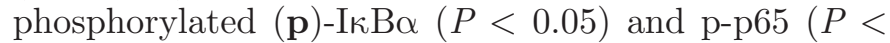
0.01 ) were significantly higher in the $\mathrm{HC}$ group than in the LC group. Compared with the $\mathrm{LC}$ diet, the ratios of $\mathrm{p}-\mathrm{I} \kappa \mathrm{B} \alpha$ and $\mathrm{I} \kappa \mathrm{B} \alpha(P<0.05)$ and of p-p65 and p65 $(P<0.01)$ expression were significantly increased in the HC diet. Additionally, IL-1 $\alpha(P<0.01)$, IL-1 $\beta$ ( $P$ $<0.01)$, and TNF- $\alpha(P<0.01)$ protein expression in the mammary tissue of the dairy cows was higher in the $\mathrm{HC}$ diet than in the LC diet (Figure 4 G-J). These results indicated that the $\mathrm{HC}$ diet activated the NF- $\kappa \mathrm{B}$ pathway and upregulated the expression of inflammatory factors.

\section{Effects of a HC Diet on ERS in the Mammary Tissue of Dairy Cows}

The mRNA expression levels of GRP78 $(P<0.01)$, CHOP $(P<0.05)$, IRE1A $(P<0.05)$, ATF6 $(P<0.05)$, and PERK $(P<0.05)$ in the mammary tissue were significantly increased in the HC group compared with the LC group (Figure 5A). Western blotting was used to detect the effect of the $\mathrm{HC}$ diet on the expression of ER stress proteins. As shown in Figure $5 \mathrm{~B}-\mathrm{D}$, the protein expression levels of PERK $(P<0.05)$, ATF6 $(P<0.05)$, IRE1 $\alpha(P<0.01)$, GRP78 $(P<0.01)$, and CHOP $(P<0.05)$ in the HC group were significantly higher than those in the LC group. The protein expression levels of p-PERK and p-IRE1 $\alpha$ were significantly increased in the $\mathrm{HC}$ group. The $\mathrm{HC}$ diet significantly upregulated the expression of ER stress marker molecules, which indicated that a high-concentrate diet could induce ER stress in the mammary tissue of dairy cows. CHOP is a proapoptotic transcription factor, and
A

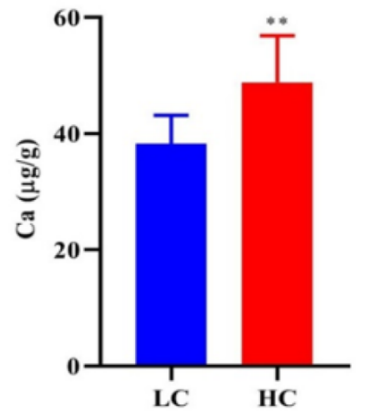

B

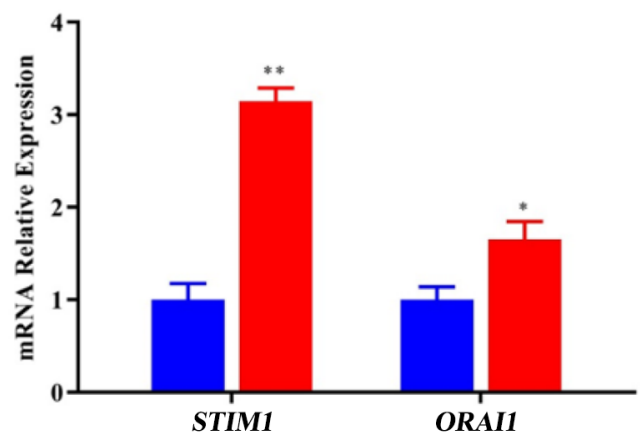

C

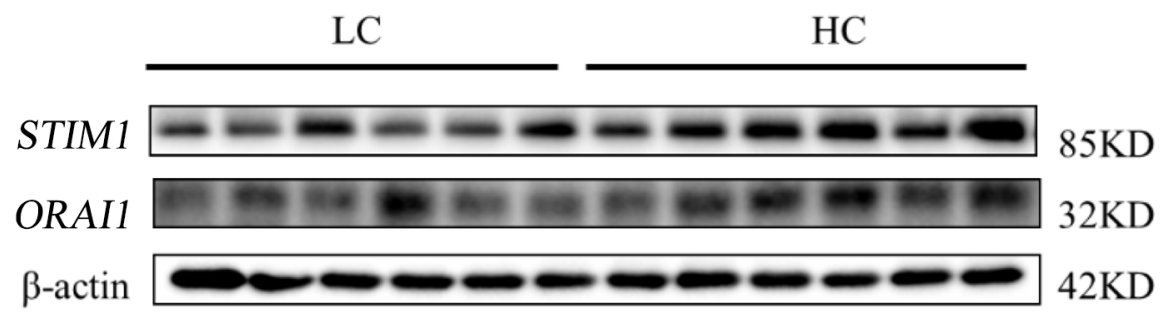

D
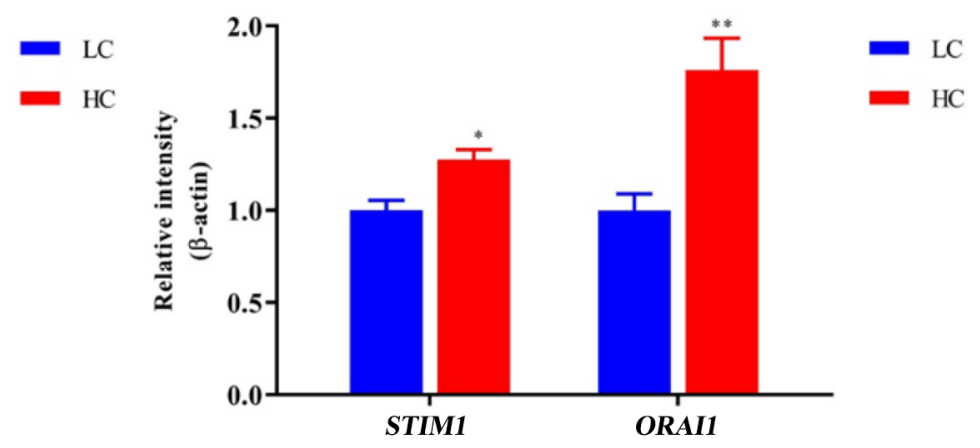

Figure 2. Effect of a high-concentrate diet on the store-operated calcium entry channel. The concentration of $\mathrm{Ca}^{2+}$ in mammary tissue of low-concentrate (LC) and high-concentrate (HC) diets (A); relative mRNA expression of STIM1 and ORAI1 (B); the protein abundances of STIM1 and ORAI1 were observed in the LC and HC diets $(\mathrm{C}, \mathrm{D})$. The data were analyzed with independent samples $t$-tests and expressed as the mean \pm SEM ( $\mathrm{n}=6$ per group). ${ }^{*} P<0.05 ;{ }^{* *} P<0.01$. 
A

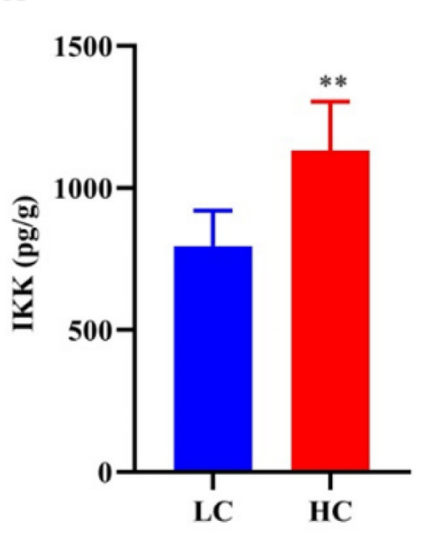

B

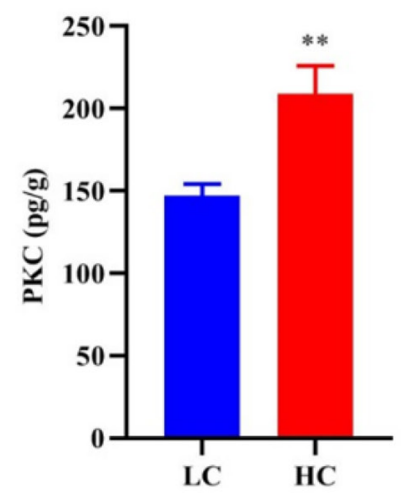

$\mathrm{C}$

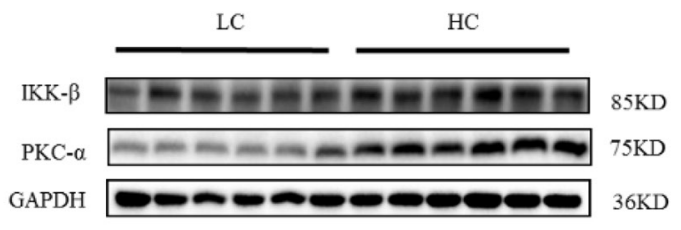

$\mathrm{D}$

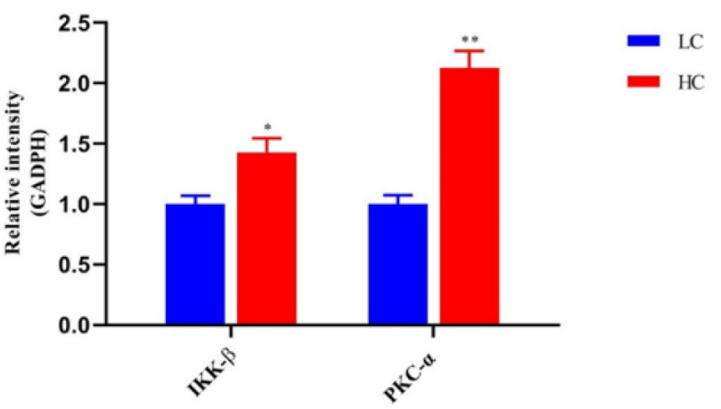

Figure 3. Effects of a high-concentrate diet on the protein expression and enzyme activity of IKK and PKC in the mammary tissue of dairy cows. The activity of the IKK and PKC kinases in the low-concentrate (LC) and high-concentrate (HC) diets (A, B); protein abundance levels of IKK- $\beta$ and PKC- $\alpha$ in the mammary tissue of cows on the LC and HC diets, with representative bands of the western blot analysis (C) and the quantified volume of specific bands (D) shown. The results are presented as the means \pm SEM. ${ }^{*} P<0.05 ;{ }^{* *} P<0.01$.

the mRNA and protein expression levels of CHOP were upregulated by the $\mathrm{HC}$ diet. Therefore, the following study was conducted to investigate whether a $\mathrm{HC}$ diet promoted apoptosis in the mammary tissue of dairy cows.

\section{Effects of a HC Diet on Mammary Tissue Apoptosis in Dairy Cows}

The enzyme activities of caspase- $3(P<0.01)$ and caspase-9 $(P<0.01)$ in the mammary tissue were higher in the $\mathrm{HC}$ group than in the LC group. However, there was no difference $(P>0.05)$ in caspase- 8 between the 2 diets (Figure 6A). Additionally, CASP3 $(P<$ $0.05), C A S P 9(P<0.05)$, and $B A X(P<0.01)$ mRNA expression in the $\mathrm{HC}$ group was higher than that in the LC group. However, BCL2 mRNA expression was significantly lower in the $\mathrm{HC}$ group than in the LC group $(P<0.05)$. The ratio of $B A X$ and $B C L 2$ in the HC group was significantly higher $(P<0.01)$ than that in the LC group (Figure 6B). The protein expression levels of caspase-3 $(P<0.05)$, activated caspase-3 $(P<$ $0.05)$, and caspase-9 $(P<0.01)$ in the HC group were markedly higher than those in the LC group, and the protein expression of BAX was significantly increased in the $\mathrm{HC}$ group $(P<0.01)$. However, Bcl-2 protein expression was significantly decreased in the HC group compared with the LC group $(P<0.01)$. The ratio of BAX and Bcl-2 in the HC group was significantly higher $(P<0.01)$ than that in the LC group (Figure 6C and Figure 6D). Our results showed that the $\mathrm{HC}$ diet induced apoptosis in the mammary tissue of dairy cows by upregulating proapoptotic proteins and downregulating antiapoptotic proteins.

\section{Histopathological Analysis of the Mammary Tissue}

According to the immunohistochemistry staining results, the HC diet significantly increased the expression of STIM1, ORAI1, GRP78, and caspase-9 in mammary tissue. Additionally, the percentages of positive areas of STIM1 $(P<0.01)$, ORAI1 $(P<0.01)$, GRP78 $(P$ $<0.01)$, and caspase-9 $(P<0.01)$ were significantly higher than those of cows on the LC diet, as shown in Figure 7.

\section{DISCUSSION}

Due to the shortage of high-quality roughage, a large amount of concentrate forage is usually used as feed to increase milk yield. Although it can improve milk yield in a short time to a certain extent, it seriously affects the ruminal health of cows (Dai et al., 2020). The low crude fiber content in a high-concentrate diet not only affects the rumination and chewing times of cows but also reduces the saliva secretion of cows (Yang and Beauchemin, 2007). Due to the effect of rapid rumen fermentation, the ruminal $\mathrm{pH}$ will be reduced. Under normal conditions, ruminal $\mathrm{pH}$ is between 6 and 7 , which can promote the growth of rumen microorgan- 
isms. When the ruminal $\mathrm{pH}$ is lower than 6 , the normal proliferation of microorganisms, especially bacteria that decompose fibrous material, will be seriously affected. When the ruminal $\mathrm{pH}$ falls below 5.6 for more than 3 $\mathrm{h}$ within $1 \mathrm{~d}$, this causes SARA (Gozho et al., 2005; Penner et al., 2010). Long-term exposure to SARA can lead to systemic inflammatory reactions in dairy cows, which seriously harms the health of dairy cows, thus reducing milk yield and milk quality (Plaizier et al., 2018). In the SARA state, a large amount of LPS, released by the breakage of gram-negative bacteria in the rumen, crosses the epithelial barrier of the digestive tract, transfers to the circulatory system, and migrates to the mammary tissue, which causes an inflammatory response in the mammary tissue and produces a large number of cytokines and acute phase proteins (Derakhshani et al., 2018).
The preliminary study of our research group showed that milk protein was significantly decreased in the $\mathrm{HC}$ group after 15 wk of feeding and that LPS concentrations in the ruminal fluid and the lacteal artery and vein were increased in the $\mathrm{HC}$ group (Zhang et al., 2016). Our previous studies also showed that after $6 \mathrm{wk}$ of feeding dairy goats a high-concentrate diet, blood flow and LPS concentration in the portal vein, hepatic vein, and artery were significantly increased, suggesting that a high-concentrate diet can increase the LPS concentration in the blood (Chang et al., 2015b). In our experiment, the $\mathrm{pH}$ observed in the cows on the $\mathrm{HC}$ diet was significantly lower than that observed with the $\mathrm{LC}$ diet, and the ruminal $\mathrm{pH}$ was below 5.6 for more than $3 \mathrm{~h}$ per day. In addition, the $\mathrm{HC}$ diet significantly upregulated the expression of LPS in the lacteal vein compared with the LC diet. This result indicated that
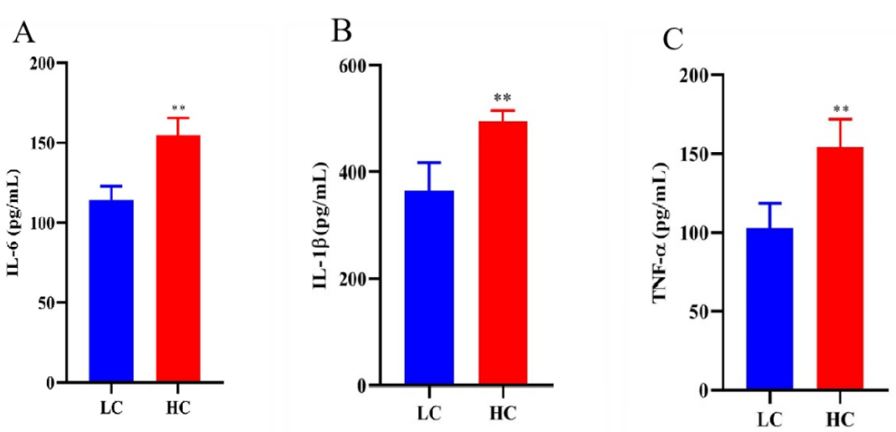

$\mathrm{D}$

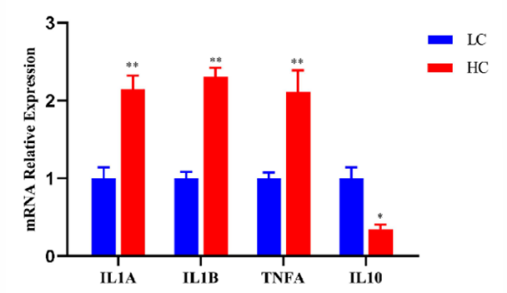

$\mathrm{E}$
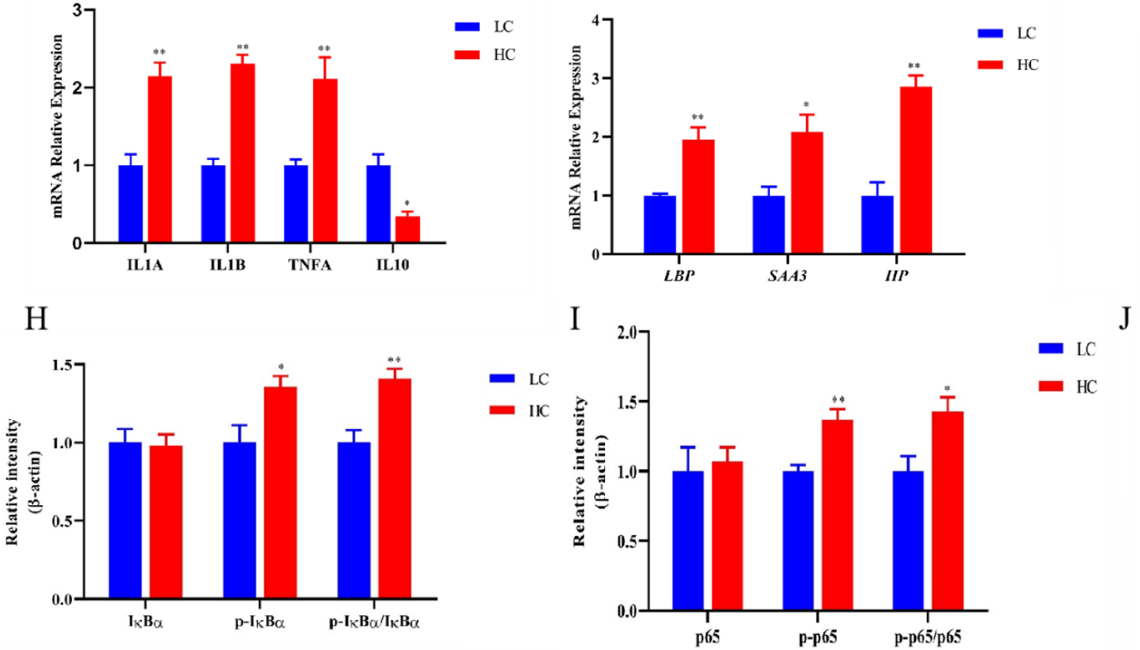

G

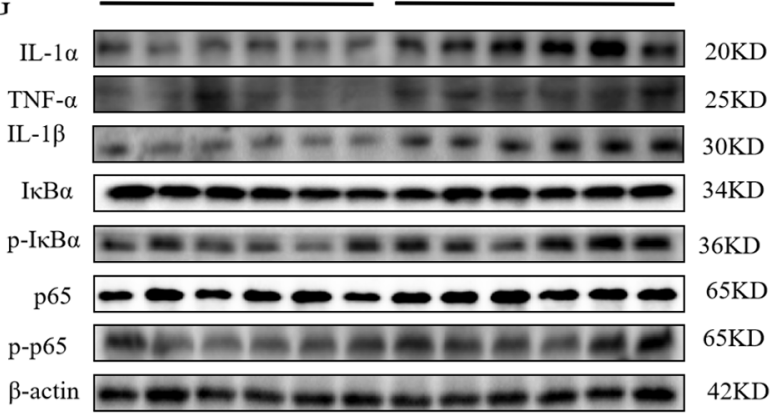

$\mathrm{F}$
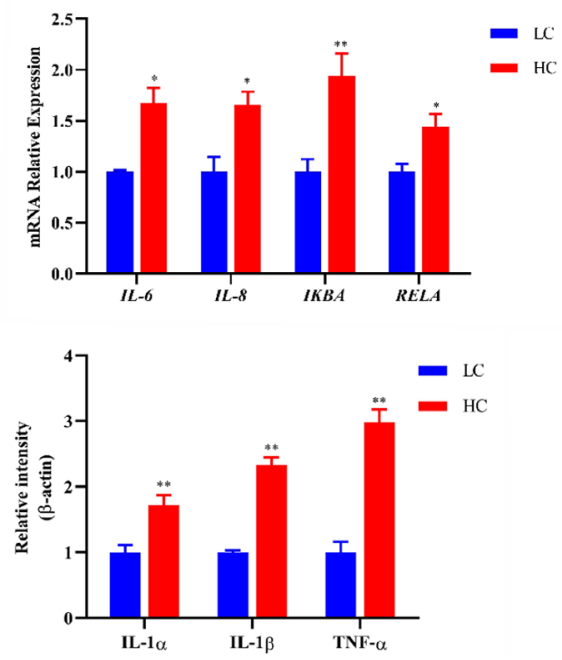

Figure 4. Effects of a high-concentrate diet on NF- $\kappa B$ activation in the mammary tissue of dairy cows. Concentrations of inflammatory cytokines (IL-1 $\beta$, IL-6, and TNF- $\alpha$ ) in the plasma of the blood harvested from cows fed the low-concentrate (LC) and high-concentrate (HC) diets $(\mathrm{A}-\mathrm{C})$; relative mRNA abundance of the genes related to inflammatory response in the mammary tissue of the cows fed the HC or LC $\operatorname{diet}(\mathrm{D}-\mathrm{F})$; effect of the $\mathrm{HC}$ diet on the protein expression of the NF- $\kappa \mathrm{B}$ signaling pathway-related proteins and on IL-1 $\alpha$, IL-1 $\beta$, and TNF- $\alpha$ in the mammary tissue $(\mathrm{G}-\mathrm{J})$. Protein expression was normalized to the respective abundance of $\beta$-actin. All results are expressed as the mean \pm SEM. ${ }^{*} P<0.05 ; * * P<0.01$. 
A

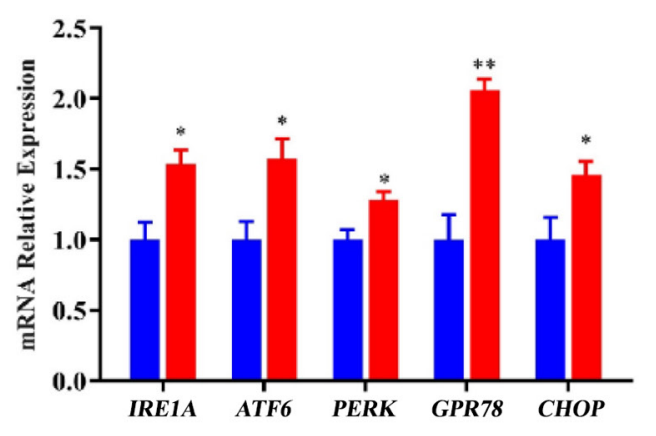

$\mathrm{C}$

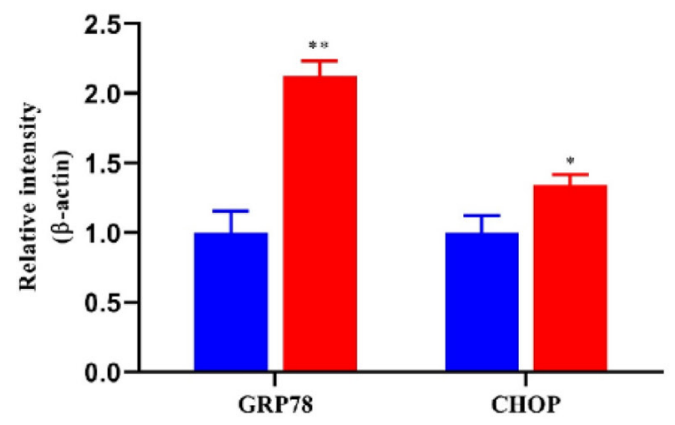

$\mathrm{B}$

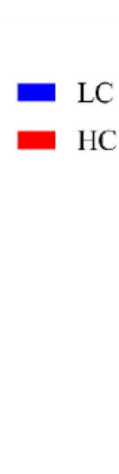
LC $\mathrm{HC}$

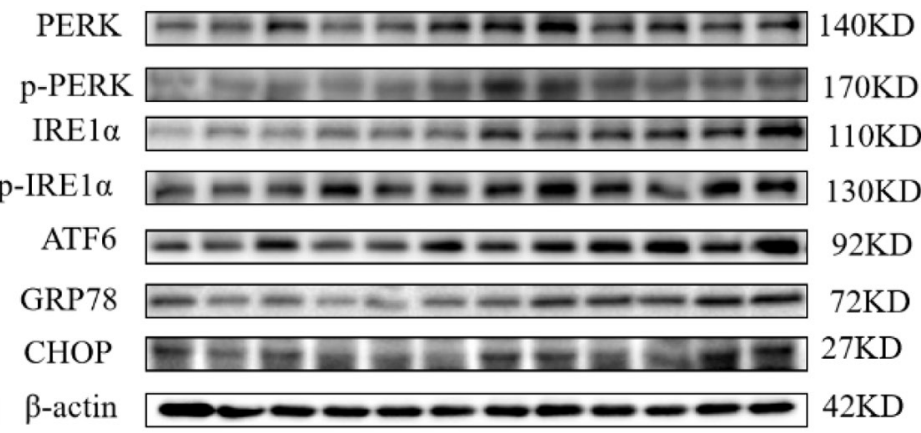

$\mathrm{D}$
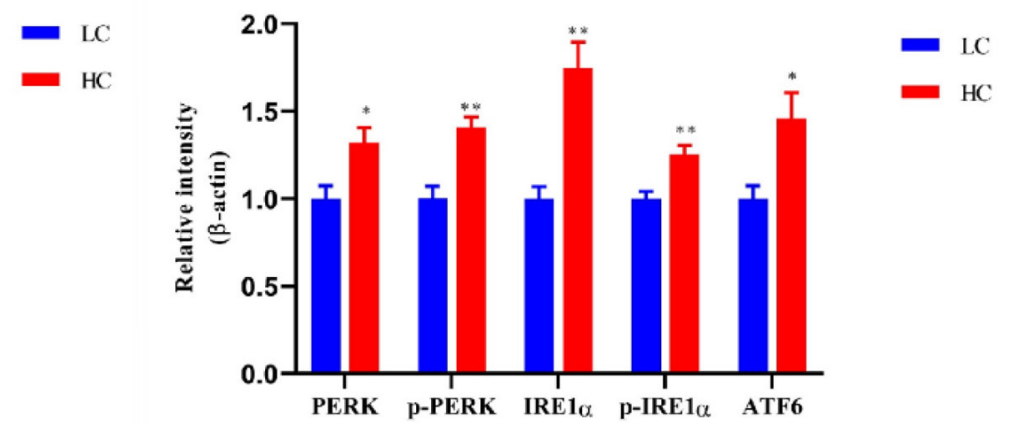

Figure 5. Effects of a high-concentrate diet on endoplasmic reticulum stress in the mammary tissue of dairy cows. Relative mRNA abundance of endoplasmic reticulum stress-related genes in the mammary tissue of dairy cows fed the low-concentrate (LC) and high-concentrate (HC) diets (A); endoplasmic reticulum stress-related proteins in the mammary tissue of cows fed the LC and HC diets. Representative bands of the western blot analysis (B). Relative protein abundances of PERK, IRE1 $\alpha$, and ATF6 (C). Relative protein abundances of GRP78 and CHOP (D). The data were analyzed with paired $t$-tests and expressed as the mean \pm SEM. ${ }^{*} P<0.05 ;{ }^{* *} P<0.01$.

the HC diet successfully induced SARA and caused a large amount of LPS to enter the mammary tissue through the blood.

Calcium $\left(\mathrm{Ca}^{2+}\right)$ is an important second messenger in cells and has important biological effects. Calcium reservoir-controlled calcium influx is the main mechanism of $\mathrm{Ca}^{2+}$ influx in nonexcitatory cells and is mainly composed of STIM1 and ORAI1 (Zhang et al., 2010). STIM1 is a calcium sensor located on the ER that can transmit the signal of $\mathrm{ER} \mathrm{Ca}^{2+}$ storage depletion to ORAI1 on the plasma membrane, which leads to SOCE opening and $\mathrm{Ca}^{2+}$ influx (Zhang et al., 2005; Prakriya et al., 2006). Therefore, we assessed the gene and protein expression of the SOCE-related proteins STIM1 and ORAI and found that the gene and protein expression of STIM1 and ORAI1 and the concentration of $\mathrm{Ca}^{2+}$ in the mammary tissues of dairy cows were significantly increased by the $\mathrm{HC}$ diet compared with the LC diet. These results indicated that the $\mathrm{HC}$ diet can activate the SOCE channel and induce extracellular $\mathrm{Ca}^{2+}$ influx by upregulating STIM1 and ORAI1 gene and protein expression in the mammary tissue of dairy cows. Exces- sive $\mathrm{Ca}^{2+}$ in the cytoplasm can interact with $\mathrm{PKC} \theta$ to activate IKK (I $\kappa$ B kinase), which can degrade IKK, and then induce the translocation of NF- $\kappa \mathrm{B}$ into the nucleus and promote the expression of inflammatory factors (Liu et al., 2016b). Calcium can also directly act on NF- $\kappa \mathrm{B}$ by stimulating $\mathrm{PKC} \alpha$, phosphorylating Ser-536 of NF- $\kappa B$ p65 and causing an increase in inflammatory factors (Liu et al., 2016b). Studies have shown that inhibition of STIM1 expression can reduce the expression of inflammatory factors. In mast cells of STIM1-deficient mice, $\mathrm{Ca}^{2+}$ influx was inhibited, as was the activation of the transcription factor NF- $\kappa \mathrm{B}$ (Baba et al., 2008). This is consistent with our results that the $\mathrm{HC}$ diet significantly increased the activity of the PKC and IKK kinases and their protein expressions, promoted the translocation of NF- $\kappa \mathrm{B}$ into the nucleus, and increased the expression of inflammatory factor genes and proteins. These results indicated that the $\mathrm{HC}$ diet can induce SOCE channel opening and extracellular $\mathrm{Ca}^{2+}$ influx by upregulating the expression of STIM1 and ORAI1. On one hand, the increased intracellular $\mathrm{Ca}^{2+}$ disconnects $\mathrm{I} \kappa \mathrm{B}$ from p65 by activating the IKK 
kinase; on the other hand, it directly translocates p65 into the nucleus by acting on PKCQ, thus causing the release of inflammatory factors and causing inflammatory damage to the mammary tissue of dairy cows.

The increase in intracellular $\mathrm{Ca}^{2+}$ levels comes both from the influx of extracellular calcium ions and from the ER. The ER is an important organelle for cellular protein synthesis, folding and modification, and $\mathrm{Ca}^{2+}$ storage (Kapoor and Sanyal, 2009). The ER can sensitively sense pressure from the outside world as an early stress response of the body (Zhang and Kaufman, 2004). In the absence of external stimulation, IRE1 $\alpha$, PERK, and ATF6 bind to the molecular chaperone GRP78 to form an inactive complex. When ER homeostasis is damaged by various factors, which increase unfolded proteins or calcium imbalance, GRP78 disengages from IRE1 $\alpha$, PERK, and ATF6, and protein expression is upregulated (Szegezdi et al., 2006; Rutkowski and Kaufman, 2007; Cnop et al., 2012). The 3 pathways of IRE1 $\alpha$, PERK, and ATF6 work together to promote the expression of CHOP, leading to ERS (Gorman et al., 2012; Hetz, 2012). Therefore, changes in the expression levels of GRP78 and CHOP have become markers of ERS (Lee, 2005). In this study, the mRNA and protein expression levels of GRP78 were significantly higher in mammary tissues of dairy cows fed the $\mathrm{HC}$ diet than in those fed the LC diet. The mRNA and protein expression levels of the transmembrane receptors IRE1 $\alpha$, PERK, and ATF6 on the ER and phospho-PERK and phospho-IRE1 $\alpha$ were significantly upregulated in the $\mathrm{HC}$ diet. These results indicated that the $\mathrm{HC}$ diet could induce ERS and activate the UPR pathway in the mammary tissue of dairy cows. Previous research showed that silencing ORAI1 in bovine mammary epithelial cells prevented the increase in the expression of endoplasmic reticulum stress-related proteins induced by BHB (Zhang et al., 2020). The results indicated that the $\mathrm{HC}$ diet significantly increased the gene and protein expression of ORAI1. Therefore, the HC diet may activate SOCE channels and lead to large amounts of $\mathrm{Ca}^{2+}$ influx through upregulation of ORAI1 expression, triggering ERS.

The ERS can mediate apoptosis through the caspase-12 and JNK pathways and CHOP/GADD153
A

B
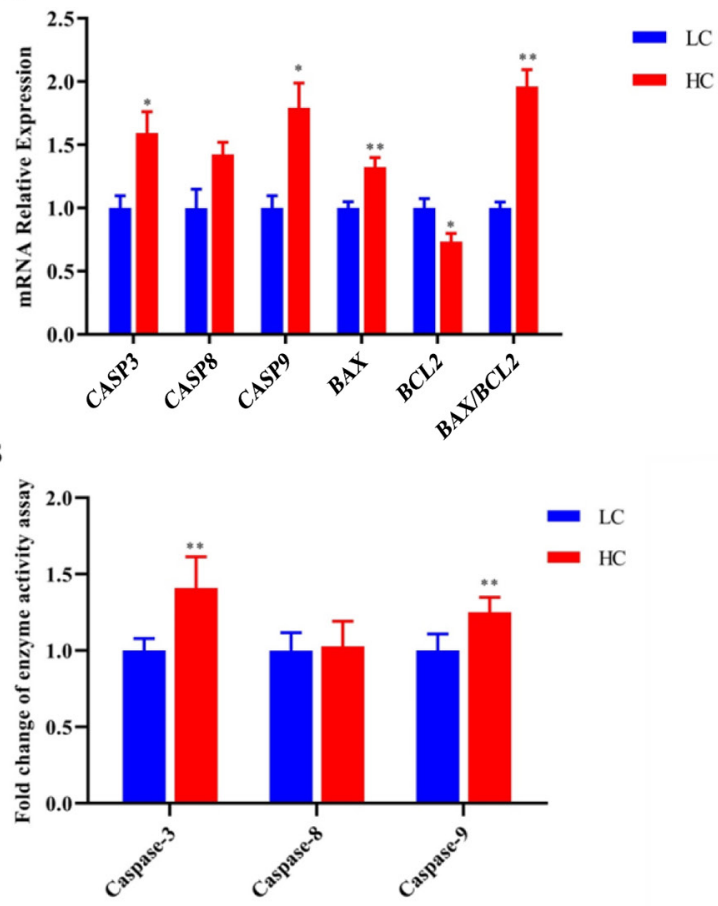

C

Caspase-3

Cleaved-Caspase-3

Caspase-9

BAX

Bcl-2

$\beta$-actin

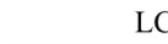

LC

$\mathrm{HC}$

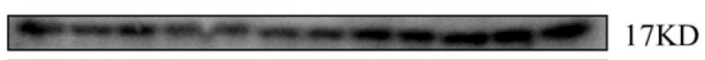

- $-17 \mathrm{KD}$

-

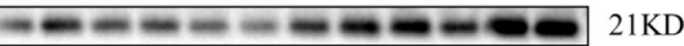

2- $28 \mathrm{KD}$

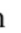

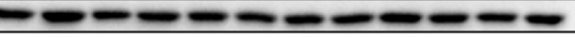

$42 \mathrm{KD}$

D

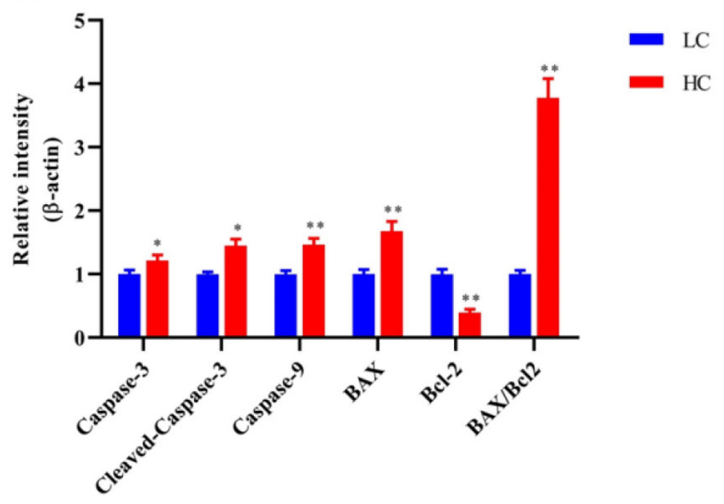

Figure 6. Effects of a high-concentrate diet on apoptosis in the mammary tissue in dairy cows. Relative mRNA abundance of the genes related to apoptosis in the mammary tissue of the cows fed the low-concentrate (LC) and high-concentrate (HC) diets (A); determination of caspase-3, caspase-8, and caspase-9 enzyme activity in the mammary tissue of dairy cows (B); protein abundance of apoptotic protein in the mammary tissue of the dairy cows fed the $\mathrm{HC}$ and LC diets. Representative bands of the western blot analysis (C); quantified volume of specific bands (D). Data are presented as the relative protein abundance relative to $\beta$-actin (means \pm SEM). ${ }^{*} P<0.05 ;{ }^{* *} P<0.01$. 
A

\section{STIM1}

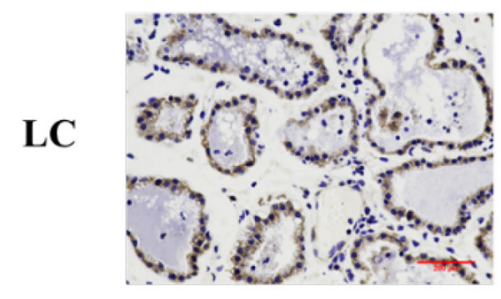

HC

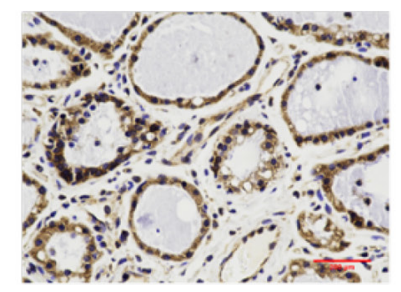

ORAI1
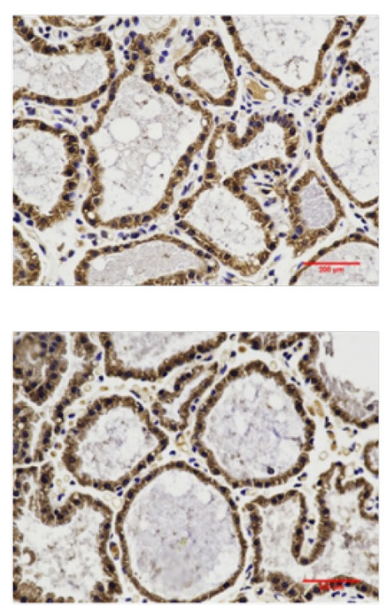

GRP78
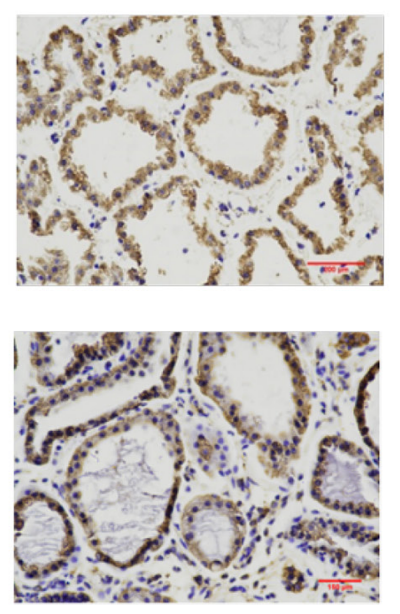

Caspase-9
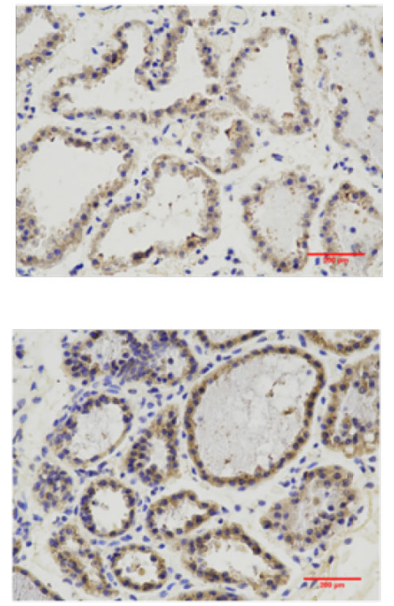

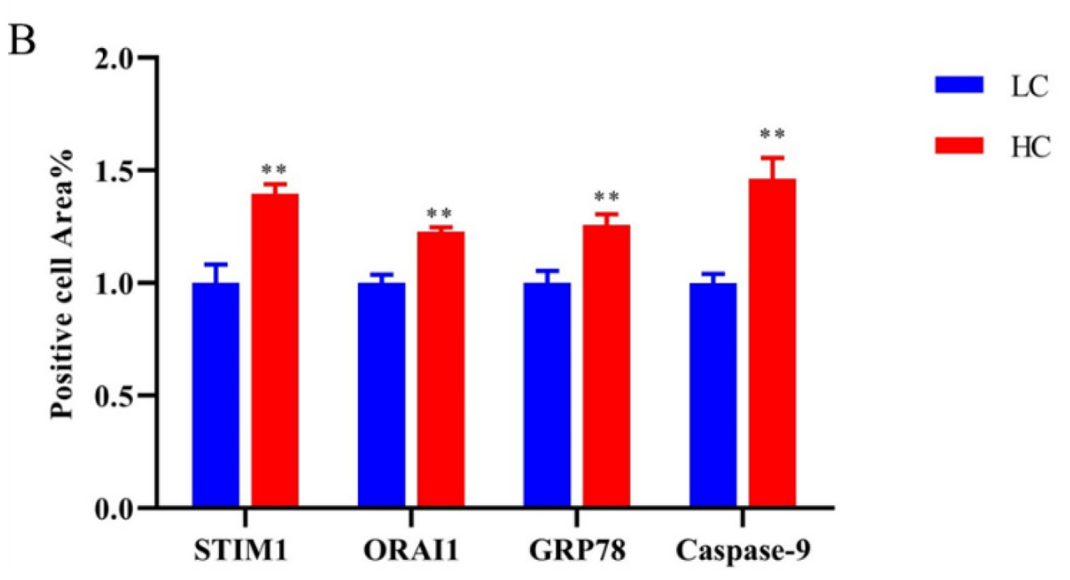

Figure 7. Sections of mammary tissue immunostained for STIM1, ORAI1, GRP78, and caspase-9 from dairy cows fed the low-concentrate (LC) and high-concentrate (HC) diets (400× magnification). Scale bar $=150 \mu \mathrm{m}$. Quantification of the numbers (mean \pm SEM) of the positive cell areas are shown in $\mathrm{B} .{ }^{* *} P<0.01$.

gene transcription (Liu et al., 2016a). CHOP is a key proapoptotic transcription factor that is closely associated with ER stress and is expressed at low levels in the absence of stimulation. The abundance of CHOP is upregulated when cells are exposed to stressors (Ron and Walter, 2007). CHOP causes mitochondrial dysfunction and apoptotic cell death by upregulating BH3 proteins (such as BAX; Anding et al., 2007; McCullough et al., 2001; Verfaillie et al., 2012), which can also inhibit the transcription of the antiapoptotic gene $B c l-2$ and destroy the balance between Bcl-2 and the proapoptotic protein BAX, thus activating endogenous apoptosis (Tamaki et al., 2017). Previous studies showed that the overexpression of CHOP can dephosphorylate p-eIF $2 \alpha$ and then improve the protein translation level and increase the protein load, thus inducing cell apoptosis (Lu et al., 2014). Other studies have shown that the elimination of CHOP from cells can reduce ERSinduced protein aggregation in the ER and reduce the levels of oxidative stress and apoptosis (Marciniak et al., 2004; Song et al., 2008). The siRNA knockdown of CHOP was shown to significantly inhibit the apoptosis of gastric cancer cells and reverse the increase in the ratio of $\mathrm{BAX} / \mathrm{Bcl}-2$ proteins induced by $\mathrm{E}$ Platinum. Silencing CHOP was also shown to inhibit the activation of caspase-9 and caspase-3 induced by E Platinum (Wang et al., 2017). Studies have shown that by interfering with the expression of STIM1 and ORAI1, intracellular $\mathrm{Ca}^{2+}$ concentration and cytochrome C release can be reduced, thereby inhibiting hepatocyte apoptosis (Cui et al., 2015). In this study, the HC diet significantly increased the expression of CHOP and induced apoptosis by inhibiting the expression of the antiapoptotic protein Bcl-2 and promoting the expres- 
sion of the proapoptotic protein BAX, leading to the chronic activation of caspase-3. Thus, the HC diet not only induced ERS but also activated ERS-mediated apoptosis signals.

\section{CONCLUSIONS}

Feeding an $\mathrm{HC}$ diet significantly decreased ruminal $\mathrm{pH}$ and increased the LPS level in lacteal vein blood of dairy cows. The LPS activated the SOCE channel by upregulating expression of STIM1 and ORAI1, thus increasing calcium content and activities of IKK and $\mathrm{PKC}$ in the mammary tissue. It then induced the activation of NF- $\kappa \mathrm{B}$ p65, which led to enhanced expression of inflammatory factors, thus causing an inflammatory response in bovine mammary tissue. In addition, feeding an $\mathrm{HC}$ diet caused ERS and apoptosis in bovine mammary tissue, which led to damage to bovine mammary tissue. These results provided a new perspective on the molecular mechanism of mastitis in dairy cows fed an $\mathrm{HC}$ diet. The effects of the SOCE signaling pathway on inflammation, ERS, and apoptosis in mammary tissue need to be further verified in cellular experiments.

\section{ACKNOWLEDGMENTS}

This study was financially supported by grants from the National Natural Science Foundation of China (grants 31872528 and 32172933; Beijing, China), the Fundamental Research Funds for the Central Universities (JCQY201905; Beijing, China), and the Priority Academic Program Development of Jiangsu Higher Education Institutions (PAPD; Nanjing, China). The authors have not stated any conflicts of interest.

\section{REFERENCES}

Anding, A. L., J. S. Chapman, D. W. Barnett, R. W. Curley Jr., and M. Clagett-Dame. 2007. The unhydrolyzable fenretinide analogue 4-hydroxybenzylretinone induces the proapoptotic genes GADD153 (CHOP) and Bcl-2-binding component 3 (PUMA) and apoptosis that is caspase- dependent and independent of the retinoic acid receptor. Cancer Res. 67:6270-6277. https://doi.org/10 .1158/0008-5472.CAN-07-0727.

Baba, Y., K. Nishida, Y. Fujii, T. Hirano, M. Hikida, and T. Kurosaki. 2008. Essential function for the calcium sensor STIM1 in mast cell activation and anaphylactic responses. Nat. Immunol. 9:81-88. https://doi.org/10.1038/ni1546.

Berridge, M. J., M. D. Bootman, and H. L. Roderick. 2003. Calcium signalling: dynamics, homeostasis and remodelling. Nat. Rev. Mol. Cell Biol. 4:517-529. https://doi.org/10.1038/nrm1155.

Brough, D., M. J. Schell, and R. F. Irvine. 2005a. Agonist-induced regulation of mitochondrial and endoplasmic reticulum motility. Biochem. J. 392:291-297. https://doi.org/10.1042/BJ20050738.

Brough, D., Y. Sim, P. Thorn, and R. F. Irvine. 2005b. The structural integrity of the endoplasmic reticulum, and its possible regulation by inositol 1,3,4,5-tetrakisphosphate. Cell Calcium 38:153-159. https://doi.org/10.1016/j.ceca.2005.05.002.
Chang, G., K. Zhang, T. Xu, D. Jin, H. M. Seyfert, X. Shen, and S. Zhuang. 2015a. Feeding a high-grain diet reduces the percentage of LPS clearance and enhances immune gene expression in goat liver. BMC Vet. Res. 11:67. https://doi.org/10.1186/s12917-015-0376-y.

Chang, G., S. Zhuang, H. M. Seyfert, K. Zhang, T. Xu, D. Jin, J. Guo, and X. Shen. 2015b. Hepatic TLR4 signaling is activated by LPS from digestive tract during SARA, and epigenetic mechanisms contribute to enforced TLR4 expression. Oncotarget 6:38578-38590. https://doi.org/10.18632/oncotarget.6161.

Cnop, M., F. Foufelle, and L. A. Velloso. 2012. Endoplasmic reticulum stress, obesity and diabetes. Trends Mol. Med. 18:59-68. https:// doi.org/10.1016/j.molmed.2011.07.010.

Cui, R., B. L. H. Yan, Z. Luo, X. L. Guo, and M. Yan. 2015. Blockade of store-operated calcium entry alleviates ethanol-induced hepatotoxicity via inhibiting apoptosis. Toxicol. Appl. Pharmacol. 287:52-66. https://doi.org/10.1016/j.taap.2015.05.014.

Dai, H., N. Ma, G. Chang, Z. U. Aabdin, and X. Shen. 2020. Longterm high-concentrate diet feeding induces apoptosis of rumen epithelial cells and inflammation of rumen epithelium in dairy cows. Anim. Biotechnol. 1-8. https://doi.org/10.1080/10495398.2020 .1806073 .

Debant, M., M. Burgos, P. Hemon, P. Buscaglia, T. Fali, S. Melayah, N. Le Goux, C. Vandier, M. Potier-Cartereau, J. O. Pers, A. Tempescul, C. Berthou, C. Bagacean, O. Mignen, and Y. Renaudineau. 2019. STIM1 at the plasma membrane as a new target in progressive chronic lymphocytic leukemia. J. Immunother. Cancer 7:111. https://doi.org/10.1186/s40425-019-0591-3.

Derakhshani, H., K. B. Fehr, S. Sepehri, D. Francoz, J. De Buck, H. W. Barkema, J. C. Plaizier, and E. Khafipour. 2018. Invited review: Microbiota of the bovine udder: Contributing factors and potential implications for udder health and mastitis susceptibility. J. Dairy Sci. 101:10605-10625. https://doi.org/10.3168/jds.2018 $-14860$.

Derler, I., C. Butorac, A. Krizova, M. Stadlbauer, M. Muik, M. Fahrner, I. Frischauf, and C. Romanin. 2018. Authentic CRAC channel activity requires STIM1 and the conserved portion of the Orai $\mathrm{N}$ terminus. J. Biol. Chem. 293:1259-1270. https://doi.org/10.1074/ jbc.M117.812206.

Fahrner, M., S. K. Pandey, M. Muik, L. Traxler, C. Butorac, M. Stadlbauer, V. Zayats, A. Krizova, P. Plenk, I. Frischauf, R. Schindl, H. J. Gruber, P. Hinterdorfer, R. Ettrich, C. Romanin, and I. Derler. 2018. Communication between $\mathrm{N}$ terminus and loop2 tunes Orai activation. J. Biol. Chem. 293:1271-1285. https://doi.org/10 .1074/jbc.M117.812693.

Fernández-Bautista, N., L. Fernández-Calvino, A. Muñoz, and M. M. Castellano. 2017. HOP3, a member of the HOP family in Arabidopsis, interacts with $\mathrm{BiP}$ and plays a major role in the ER stress response. Plant Cell Environ. 40:1341-1355. https://doi.org/10 $.1111 /$ pce. 12927 .

Gorman, A. M., S. J. M. Healy, R. Jäger, and A. Samali. 2012. Stress management at the ER: Regulators of ER stress-induced apoptosis. Pharmacol. Ther. 134:306-316. https://doi.org/10.1016/j .pharmthera.2012.02.003.

Gozho, G. N., D. O. Krause, and J. C. Plaizier. 2007. Ruminal lipopolysaccharide concentration and Inflammatory response during grain-induced subacute ruminal acidosis in dairy cows. J. Dairy Sci. 90:856-866. https://doi.org/10.3168/jds.S0022-0302(07)71569 -2 .

Gozho, G. N., J. C. Plaizier, D. O. Krause, A. D. Kennedy, and K. M. Wittenberg. 2005. Subacute ruminal acidosis induces ruminal lipopolysaccharide endotoxin release and triggers an inflammatory response. J. Dairy Sci. 88:1399-1403. https://doi.org/10.3168/jds .S0022-0302(05)72807-1.

Gregory, R. B., R. Hughes, A. M. Riley, B. V. L. Potter, R. A. Wilcox, and G. J. Barritt. 2004. Inositol trisphosphate analogues selective for types I and II inositol trisphosphate receptors exert differential effects on vasopressin-stimulated $\mathrm{Ca}^{2+}$ inflow and $\mathrm{Ca}^{2+}$ release from intracellular stores in rat hepatocytes. Biochem. J. 381:519-526. https://doi.org/10.1042/BJ20040637. 
Hetz, C. 2012. The unfolded protein response: Controlling cell fate decisions under ER stress and beyond. Nat. Rev. Mol. Cell Biol. 13:89-102. https://doi.org/10.1038/nrm3270.

Kapoor, A., and A. J. Sanyal. 2009. Endoplasmic reticulum stress and the unfolded protein response. Clin. Liver Dis. 13:581-590. https:/ /doi.org/10.1016/j.cld.2009.07.004.

Karacicek, B., Y. Erac, and M. Tosun. 2019. Functional consequences of enhanced expression of STIM1 and Orai1 in Huh-7 hepatocellular carcinoma tumor-initiating cells. BMC Cancer 19:751. https: //doi.org/10.1186/s12885-019-5947-z.

Lee, A. S. 2005. The ER chaperone and signaling regulator GRP78/ $\mathrm{BiP}$ as a monitor of endoplasmic reticulum stress. Methods 35:373-381. https://doi.org/10.1016/j.ymeth.2004.10.010.

Li, X., G. Wu, Y. Yang, S. Fu, X. Liu, H. Kang, X. Yang, X.-C. $\mathrm{Su}$, and Y. Shen . 2017. Calmodulin dissociates the STIM1-Orai1 complex and STIM1 oligomers. Nat. Commun. 8:1042. https://doi .org/10.1038/s41467-017-01135-w.

Liu, M., Z. Chen, and L. Chen. 2016a. Endoplasmic reticulum stress: A novel mechanism and therapeutic target for cardiovascular diseases. Acta Pharmacol. Sin. 37:425-443. https://doi.org/10.1038/ aps.2015.145.

Liu, X., C. T. Berry, G. Ruthel, J. J. Madara, K. Macgillivray, C. M. Gray, L. A. Madge, K. A. Mccorkell, D. P. Beiting, U. Hershberg, M. J. May, and B. D. Freedman. 2016b. T cell receptor-induced nuclear factor $\kappa \mathrm{B}(\mathrm{NF}-\kappa \mathrm{B})$ signaling and transcriptional activation are regulated by STIM1- and Orail-mediated calciumentry. J. Biol. Chem. 291:8440-8452. https://doi.org/10.1074/jbc.M115 .713008 .

Louessard, M., I. Bardou, E. Lemarchand, A. M. Thiebaut, J. Parcq, J. Leprince, A. Terrisse, V. Carraro, P. Fafournoux, A. Bruhat, C. Orset, D. Vivien, C. Ali, and B. D. Roussel. 2017. Activation of cell surface GRP78 decreases endoplasmic reticulum stress and neuronal death. Cell Death Differ. 24:1518-1529. https://doi.org/ 10.1038/cdd.2017.35.

Lu, M., D. A. Lawrence, S. Marsters, D. Acosta-Alvear, P. Kimmig, A. S. Mendez, A. W. Paton, J. C. Paton, P. Walter, and A. Ashkenazi. 2014. Opposing unfolded-protein-response signals converge on death receptor 5 to control apoptosis. Science 345:98-101. https://doi.org/10.1126/science.1254312.

Marciniak, S. J., C. Yun, S. Oyadomari, I. Novoa, Y. Zhang, R. Jungreis, K. Nagata, H. P. Harding, and D. Ron. 2004. CHOP induces death by promoting protein synthesis and oxidation in the stressed endoplasmic reticulum. Genes Dev. 18:3066-3077. https://doi.org/ 10.1101/gad.1250704.

McCullough, K. D., J. L. Martindale, L. O. Klotz, T. Y. Aw, and N. J. Holbrook. 2001. Gadd153 sensitizes cells to endoplasmic reticulum stress by down-regulating Bcl2 and perturbing the cellular redox state. Mol. Cell. Biol. 21:1249-1259. https://doi.org/10.1128/ MCB.21.4.1249-1259.2001.

Park, K. W., G. E. Kim, R. Morales, F. Moda, I. Moreno-Gonzalez, L. Concha Marambio, A. S. Lee, C. Hetz, and C. Soto. 2017. The endoplasmic reticulum chaperone GRP78/BiP modulates prion propagation in vitro and in vivo. Sci. Rep. 7:44723. https://doi .org/10.1038/srep44723.

Penner, G. B., M. Oba, G. Gäbel, and J. R. Aschenbach. 2010. A single mild episode of subacute ruminal acidosis does not affect ruminal barrier function in the short term. J. Dairy Sci. 93:48384845. https://doi.org/10.3168/jds.2010-3406.

Pinton, P., D. Ferrari, E. Rapizzi, F. Virgilio, and R. Rizzuto. 2001. The $\mathrm{Ca}^{2+}$ concentration of the endoplasmic reticulum is a key determinant of ceramide-induced apoptosis: Significance for the molecular mechanism of Bcl-2 action. EMBO J. 20:2690-2701. https: //doi.org/10.1093/emboj/20.11.2690.

Plaizier, J. C., M. Danesh Mesgaran, H. Derakhshani, H. Golder, E. Khafipour, J. L. Kleen, I. Lean, J. Loor, G. Penner, and Q. Zebeli. 2018. Review: Enhancing gastrointestinal health in dairy cows. Animal 12(s2):s399-s418. https://doi.org/10.1017/ S1751731118001921.
Prakriya, M., S. Feske, Y. Gwack, S. Srikanth, A. Rao, and P. G. Hogan. 2006. Orail is an essential pore subunit of the CRAC channel. Nature 443:230-233. https://doi.org/10.1038/nature05122.

Ron, D., and P. Walter. 2007. Signal integration in the endoplasmic reticulum unfolded protein response. Nat. Rev. Mol. Cell Biol. 8:519-529. https://doi.org/10.1038/nrm2199.

Rutkowski, D. T., and R. J. Kaufman. 2007. That which does not kill me makes me stronger: Adapting to chronic ER stress. Trends Biochem. Sci. 32:469-476. https://doi.org/10.1016/j.tibs.2007.09.003.

Schröder, M., and R. J. Kaufman. 2005. ER stress and the unfolded protein response. Mutat. Res. 569:29-63. https://doi.org/10.1016/ j.mrfmmm.2004.06.056.

Song, B., D. Scheuner, D. Ron, S. Pennathur, and R. J. Kaufman. 2008. Chop deletion reduces oxidative stress, improves $\beta$ cell function, and promotes cell survival in multiple mouse models of diabetes. J. Clin. Invest. 118:3378-3389. https://doi.org/10.1172/ JCI34587.

Song, X., Y. Liu, L. Dong, and Y. Wang. 2018. Stromal-interacting molecule 1 (Stim1)/Orai1 modulates endothelial permeability in ventilator-induced lung injury. Med. Sci. Monit. 24:9413-9423. https://doi.org/10.12659/MSM.911268.

Sun, S., W. Li, H. Zhang, L. Zha, Y. Xue, X. Wu, and F. Zou. 2012. Requirement for store-operated calcium entry in sodium butyrate-induced apoptosis in human colon cancer cells. Biosci. Rep. 32:83-90. https://doi.org/10.1042/BSR20110062.

Szabadkai, G., and R. Rizzuto. 2004. Participation of endoplasmic reticulum and mitochondrial calcium handling in apoptosis: More than just neighborhood? FEBS Lett. 567:111-115. https://doi .org/10.1016/j.febslet.2004.04.059.

Szegezdi, E., S. E. Logue, A. M. Gorman, and A. Samali. 2006. Mediators of endoplasmic reticulum stress-induced apoptosis. EMBO Rep. 7:880-885. https://doi.org/10.1038/sj.embor.7400779.

Tamaki, T., K. Kamatsuka, T. Sato, S. Morooka, K. Otsuka, M. Hattori, and T. Sugiyama. 2017. A novel transmembrane protein defines the endoplasmic reticulum stress-induced cell death pathway. Biochem. Biophys. Res. Commun. 486:149-155. https://doi.org/10 .1016/j.bbrc.2017.03.017.

Tamareille, S., O. Mignen, T. Capiod, C. Rücker-Martin, and D. Feuvray. 2006. High glucose-induced apoptosis through store-operated calcium entry and calcineurin in human umbilical vein endothelial cells. Cell Calcium 39:47-55. https://doi.org/10.1016/j.ceca.2005 .09 .008 .

Targos, B., J. Barańska, and P. Pomorski. 2005. Store-operated calcium entry in physiology and pathology of mammalian cells. Acta Biochim. Pol. 52:397-409. https://doi.org/10.18388/abp.2005 -3452 .

Verfaillie, T., N. Rubio, A. D. Garg, G. Bultynck, R. Rizzuto, J. P. Decuypere, J. Piette, C. Linehan, S. Gupta, A. Samali, and P. Agostinis. 2012. PERK is required at the ER-mitochondrial contact sites to convey apoptosis after ROS-based ER stress. Cell Death Differ. 19:1880-1891. https://doi.org/10.1038/cdd.2012.74.

Wang, R., M. Moniruzzaman, E. Shuffle, R. Lourie, and S. Z. Hasnain. 2018a. Immune regulation of the unfolded protein response at the mucosal barrier in viral infection. Clin. Transl. Immunology 7:e1014. https://doi.org/10.1002/cti2.1014.

Wang, W., Y. Ren, L. Wang, W. Zhao, X. Dong, J. Pan, H. Gao, and Y. Tian. 2018b. Orai1 and Stim1 mediate the majority of store-operated calcium entry in multiple myeloma and have strong implications for adverse prognosis. Cell. Physiol. Biochem. 48:2273-2285. https://doi.org/10.1159/000492645.

Wang, X., Q. Guo, L. Tao, L. Zhao, Y. Chen, T. An, Z. Chen, and R. Fu. 2017. E platinum, a newly synthesized platinum compound, induces apoptosis through ROS-triggered ER stress in gastric carcinoma cells. Mol. Carcinog. 56:218-231. https://doi.org/10.1002/ mc. 22486 .

Xu, C., B. Bailly-Maitre, and J. C. Reed. 2005. Endoplasmic reticulum stress: Cell life and death decisions. J. Clin. Invest. 115:2656-2664. https://doi.org/10.1172/JCI26373. 
Yan, J., B. Zhang, Z. Hosseinzadeh, and F. Lang. 2016. Down-regulation of store-operated $\mathrm{Ca} 2+$ Entry and $\mathrm{Na}^{+} \mathrm{Ca}^{2+}$ exchange in MCF-7 breast cancer cells by pharmacological JAK3 inhibition. Cell. Physiol. Biochem. 38:1643-1651. https://doi.org/10.1159/ 000443104.

Yang, W. Z., and K. A. Beauchemin. 2007. Altering physically effective fiber intake through forage proportion and particle length: Digestion and milk production. J. Dairy Sci. 90:3410-3421. https: //doi.org/10.3168/jds.2006-818.

Yang, Z., L. Pan, S. Liu, F. Li, W. Lv, Y. Shu, and P. Dong. 2018. Inhibition of stromal-interacting molecule 1-mediated store-operated $\mathrm{Ca}^{2+}$ entry as a novel strategy for the treatment of acquired imatinib-resistant gastrointestinal stromal tumors. Cancer Sci. 109:2792-2800. https://doi.org/10.1111/cas.13718.

Zhang, B., M. Li, W. Yang, J. J. Loor, S. Wang, Y. Zhao, H. Guo, X. Ma, C. Xia, and C. Xu. 2020. Orai calcium release-activated calcium modulator 1 (ORAI1) plays a role in endoplasmic reticulum stress in bovine mammary epithelial cells challenged with physiological levels of ketone bodies-Science Direct. J. Dairy Sci. 103:4691-4701. https://doi.org/10.3168/jds.2019-17422.

Zhang, K., G. Chang, T. Xu, L. Xu, J. Guo, D. Jin, and X. Shen. 2016. Lipopolysaccharide derived from the digestive tract activates inflammatory gene expression and inhibits casein synthesis in the mammary glands of lactating dairy cows. Oncotarget 7:9652-9665. https://doi.org/10.18632/oncotarget.7371.

Zhang, K., and R. J. Kaufman. 2004. Signaling the unfolded protein response from the endoplasmic reticulum. J. Biol. Chem. 279:25935-25938. https://doi.org/10.1074/jbc.R400008200.

Zhang, S. L., Y. Yu, J. Roos, J. A. Kozak, T. J. Deerinck, M. H. Ellisman, K. A. Stauderman, and M. D. Cahalan. 2005. STIM1 is a $\mathrm{Ca}^{2+}$ sensor that activates CRAC channels and migrates from the $\mathrm{Ca}^{2+}$ store to the plasma membrane. Nature 437:902-905. https:// doi.org/10.1038/nature04147.

Zhang, Z.-Y., L. Pan, and Z. Zhang. 2010. Functional interactions among STIM1, Orail and TRPC1 on the activation of SOCs in HL-7702 cells. Amino Acids 39:195-204. https://doi.org/10.1007/ s00726-009-0398-5.

\section{ORCIDS}

Xiangzhen Shen ำ https://orcid.org/0000-0002-3020-5010 